This document was prepared in conjunction with work accomplished under Contract No. DE-AC09-96SR18500 with the U. S. Department of Energy.

\title{
DISCLAIMER
}

This report was prepared as an account of work sponsored by an agency of the United States Government. Neither the United States Government nor any agency thereof, nor any of their employees, makes any warranty, express or implied, or assumes any legal liability or responsibility for the accuracy, completeness, or usefulness of any information, apparatus, product or process disclosed, or represents that its use would not infringe privately owned rights. Reference herein to any specific commercial product, process or service by trade name, trademark, manufacturer, or otherwise does not necessarily constitute or imply its endorsement, recommendation, or favoring by the United States Government or any agency thereof. The views and opinions of authors expressed herein do not necessarily state or reflect those of the United States Government or any agency thereof.

This report has been reproduced directly from the best available copy.

Available for sale to the public, in paper, from: U.S. Department of Commerce, National Technical Information Service, 5285 Port Royal Road, Springfield, VA 22161, phone: (800) 553-6847, fax: (703) 605-6900

email: orders@ntis.fedworld.gov

online ordering: http://www.ntis.gov/help/index.asp

Available electronically at http://www.osti.gov/bridge

Available for a processing fee to U.S. Department of Energy and its contractors, in paper, from: U.S. Department of Energy, Office of Scientific and Technical Information, P.O. Box 62, Oak Ridge, TN 37831-0062,

phone: (865)576-8401,

fax: (865)576-5728

email: $\underline{\text { reports@ adonis.osti.gov }}$ 
[For Submission to Journal of Separation Science and Technology]

WSRC-MS-2003-00759 Key Words: DWPF Recycle Precipitation Freundlich Isotherm

\section{Removal of Silicon from High Level Waste Streams via Ferric Flocculation}

W. R. Wilmarth

J. T. Mills

V. H. Dukes

Westinghouse

Savannah River Company

Aiken, SC 29808

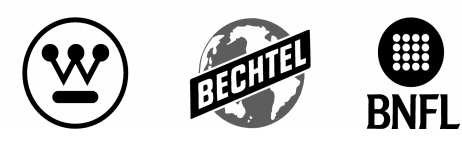


WSRC-MS-2003-00759

\title{
Removal of Silicon from High Level Waste Streams via Ferric Flocculation
}

\author{
W. R. Wilmarth, J. T. Mills, and V. H. Dukes \\ Savannah River Technology Center \\ Westinghouse Savannah River Company
}

Aiken, SC 29808

\begin{abstract}
$\underline{\text { Abstract }}$
The presence of silicate from glass-forming frit in the recycle waste from the Defense Waste Processing Facility produces wastes that when combined with the traditional aluminate-bearing wastes stored in Savannah River Site's tank farms can produce insoluble sodium aluminosilicates. Currently, aluminum--bearing wastes and siliconbearing wastes are processed in separate evaporators. This, however, limits operational flexibility. Therefore, treatment to remove silicon has been proposed to allow greater flexibility for processing these wastes in the Site's evaporators. The use of a ferric precipitation (flocculation) to remove the silicon has been tested using waste simulants.
\end{abstract}

Ferric precipitation following ferric nitrate addition to two different alkaline DWPF recycle waste simulants was effective at removing silicon to levels below concern for processing in the any of the Savannah River Site's evaporators. Removal of silicon was rapid with removal complete in 2 hours. Elevated temperatures were tested and found to be not required. Capacities of the resultant iron flocculent were $\sim 0.1 \mathrm{~g}$ of silicon per gram of iron at a final silicon concentration of $50 \mathrm{mg} / \mathrm{L}$. Moreover, the silicon removal obeys a classical Freundlich adsorption isotherm.

\section{Introduction}

Approximately 130 million liters of High Level Waste is stored at the Savannah River Site. This liquid waste was made alkaline prior to discharge from the F-and H-Canyon facilities. During storage, the liquid waste is typically evaporated to concentrated the supernate and maintain storage volume. These operations have been performed for many 
WSRC-MS-2003-00759

decades during plutonium production. The High Level Waste is typically several molar in sodium ion with large amounts of free hydroxide, nitrate, nitrite and aluminate concentrations.

In the late 1990's, the Defense Waste Processing Facility (DWPF) was commissioned to begin transforming the sludge and supernate components of the High Level Waste into a vitrified product that would be interned at the federal repository, currently slated for Yucca Mountain, NV. The DWPF returns a recycle water stream from condenser and other process operations to the tank farm. This stream is currently the largest volume source of influent to the tank farm (approximately $1-2$ million gallons produced per year). The DWPF recycle stream is very dilute ( 1M sodium ion concentration) as compared to concentrated supernate $(10-12 \mathrm{M}$ sodium ion concentration) and would be appropriate feed for evaporation. Unfortunately, the DWPF recycle stream contains silicon in the form of soluble silicates and insoluble glass-forming frit. The mixture of soluble aluminate in the historical canyon waste and the silicon from DWPF recycle led to the formation of insoluble sodium aluminosilicates in the one of the Savannah River Site's Evaporator. [1]

Operation of the High Level Waste evaporators is vital to maintain tank space to meet site mission requirements as well as regulatory commitments for closing the High Level Waste tanks. Since the aluminosilicate deposits were discovered and one evaporator was shutdown for almost 2 years, research into understanding the reaction kinetics for formation and aluminosilicate product solubilities has been performed. The results have shown that the mixture of the two tank farm streams produced waste supersaturated in aluminosilicate. The aluminosilicate can readily form and precipitate under evaporator conditions. [2]

Current waste handling processes in the tank farm segregate the high aluminate streams from the silicon-containing streams to prevent aluminosilicate formation, sending each to different evaporators. However, operational flexibility is hampered by this segregation approach. Therefore, silicon treatments for use with existing stored DWPF recycle in the 
WSRC-MS-2003-00759

tank farm along with the possible treatment inside DWPF at the point of origin of the silicon-containing waste have been examined.

One identified treatment option is the use of the addition of ferric ion to the alkaline waste resulting in the formation of an iron hydroxide floc. This treatment technology [3] removes silicon by co-precipitation and/or silicon adsorption onto the iron precipitate.

This treatment technology has been well established for municipal wastewater operations [4] but has not been tested to remove silicon from either simulated nuclear wastes or actual waste from the tank farm. Additionally, information of the ferric precipitate morphology and filtration performance are needed to assess the technology for nuclear application. Therefore, initial testing for silicon removal by ferric flocculation was performed on simulated wastes from the tanks containing stored DWPF recycle (termed Tank 20 simulant) and from a projected composition of the alkaline contents of the recycle collection tank.

\section{$\underline{\text { Experimental Details }}$}

Laboratory tests were performed on the $50 \mathrm{~mL}$ scale using the simulated wastes with the compositions shown in Table 1. As generated, the DWPF recycle is slightly acidic. The stream is neutralized prior to discharge to be compatible with the carbon steel construction of the storage tanks and its composition is shown in Table 1. Additionally, the DWPF Recycle has been stored and mixed with other waste heels. The composition of this stream, the Tank 20 simulant, is also in Table 1. The simulants were prepared from reagent grade chemicals. Silicon was added as the hydrated sodium meta-silicate salt.

The ferric precipitation agent was prepared from reagent-grade ferric nitrate and dissolved in de-ionized water to a $1 \mathrm{M} \mathrm{Fe}\left(\mathrm{NO}_{3}\right)_{3}$ concentration. Following procedures used for other ferric flocculent applications [5] tests were conducted at ambient and elevated $\left(50^{\circ} \mathrm{C}\right)$ temperatures. The silicon-bearing solutions were added to the $100 \mathrm{~mL}$ reaction vessel, heated to reaction temperature in a water bath, and stirred using a 
WSRC-MS-2003-00759

magnetic stir bar for at least 2 hours. Afterward, the ferric slurry was filtered through a $0.45 \mu \mathrm{m}$ cellulose nitrate filter. Mass measurements were performed initially and at the end of the experiment to correct measured concentrations for evaporation.

The stock solution and resulting filtrate solutions were analyzed for silicon using Inductively Coupled Plasma-Emission Spectrometer (ICP-ES) using a JY 170C, Instruments SA, Inc. Table 2 contains the silicon concentrations in the stick solutions and the treated wastes. The ferric flocculent was dried at ambient temperature and characterized using a International Scientific Instruments DS-103 Scanning Electron Microscopy (SEM) and a Noran A4105 Energy Dispersive Spectroscopy (EDS) for elemental profiling.

\section{$\underline{\text { Results and Discussion }}$}

Tank 20 Simulant (DWPF Recycle in Tank Farm)

As previously mentioned, the DWPF recycle that was generated during the period when evaporator operation was curtailed is stored in the tank farm. The volume, nearly 3 million gallons, will eventually be concentrated in the evaporator dedicated to silicon processing. However, the recycle that is currently being generated represents $\sim 70-80 \%$ of that evaporator's utility. Therefore, it is potentially desirable to remove the silicon and concentrate with the other site evaporators. A simulant with the composition previously discussed was tested for silicon removal by ferric flocculation. Shown in Figure 1 is a dosage curve for the addition of iron and the subsequent removal of silicon for a Tank 20 simulant. The starting silicon concentration was $200 \mathrm{mg} / \mathrm{L}$. The curve appears linear until $\sim 70 \%$ of the silicon is removed and then flattens out with higher addition of iron.

Figure 2 shows the measured capacity of the ferric flocculent for silicon removal as a function of the measured final silicon concentration. Tests were initially conducted at ambient laboratory temperature and $50^{\circ} \mathrm{C}$. The targeted silicon concentration that would 
WSRC-MS-2003-00759

allow the treated Tank 20 material to be processed in other site evaporators is less than 50 $\mathrm{mg} / \mathrm{L}$. The data shown in Figure 2 at a final silicon concentration below $50 \mathrm{mg} / \mathrm{L}$ did not indicate a difference between performing the tests at ambient or elevated temperature. Therefore, additional testing was conducted at ambient temperature.

The plot in Figure 2 shows silicon capacities on the order of $0.1 \mathrm{~g}$ of silicon $/ \mathrm{g}$ of iron added to reach a final silicon concentration of $50 \mathrm{mg} / \mathrm{L}$ and $0.15 \mathrm{~g} \mathrm{Si} / \mathrm{g} \mathrm{Fe}$ at $150 \mathrm{mg} / \mathrm{L}$ final silicon concentration. These capacities are higher than ferric flocculent capacity report in wastewater treatment. [4] This is most likely do to silicon being in the form of silicate ions in the caustic solution as compared to the species in $\mathrm{pH} 7$ waters. At the capacities measured in the Tank 20 simulant, ferric flocculation will remove silicon to levels allowing processing in either the aluminum-processing evaporators.

Adsorption onto solids has been studied for decades. There are two adsorption models that are traditionally used to describe the process. The Freundlich isotherm model was one of the first proposed to correlate the amount of a substance absorbed to the concentration of material in solution. Equation 1 shows the Freundlich expression where $\mathrm{m}$ is the number of grams absorbed per gram of absorbent and $\mathrm{c}$ is the sorbate concentration with $\mathrm{k}$ and $\mathrm{n}$ as constants.

$$
\mathrm{M}=\mathrm{kc}^{1 / \mathrm{n}}
$$

\section{Equation 1. Freundlich Isotherm}

The other adsorption model is the Langmuir isotherm and is very useful if only a monolayer of adsorption occurs. The data from the ambient temperature tests performed using the Tank 20 simulant was plotted using the Freundlich and Langmuir expressions. The regression of the data revealed that the adsorption of silicon on ferric flocculent did not obey the Langmuir model $\left(\mathrm{R}^{2}<0.6\right)$ but did obey the Freundlich model as shown in Figure 3. The fit of the data to the Freundlich isotherm was very good with a correlation coefficient of 0.95 . There does appear to be some aspects to a sinusoidal curve to the 
WSRC-MS-2003-00759

lower final silicon concentrations. Potentially, other adsorption models would better explain this portion of the data.

\section{Neutralized DWPF Recycle stored inside DWPF}

Recycle water is accumulated in the recycle collection tank and neutralized prior to discharge to tank farm. Though no samples of the water have been analyzed due to the difficulty in retrieving a sample, the estimated composition is provided in Table 1 . The silicon concentration in the neutralized recycle is high $(\sim 600 \mathrm{mg} / \mathrm{L})$. Therefore a wider silicon concentration range was used in ferric flocculation testing. Figure 4 shows the measured silicon isotherm for the ferric flocculent produced in the tests with neutralized DWPF recycle.

The capacity for silicon removal at a targeted $50 \mathrm{mg} / \mathrm{L}$ final concentration is approximately the same $(0.1 \mathrm{~g} \mathrm{Si} / \mathrm{g} \mathrm{Fe})$ for the neutralized recycle as the capacity measured in the Tank 20 simulant. The data were analyzed using the Freundich isotherm model and the results are shown in Figure 5. The fit for the Freundlich model is very $\operatorname{good}\left(\mathrm{R}^{2}=0.93\right)$. The silicon removal efficiency using the ferric flocculation technique appears to not vary much with small changes in solution composition. This implies that the same silicon species is being removed.

Samples from a previous scoping test in which the mother solution was spiked with very high silicon concentrations $(8 \mathrm{~g} / \mathrm{L})$ were submitted for analysis by X-ray diffraction and scanning electron microscopy. The samples were rinsed once with inhibited water $(0.01$ $\mathrm{M} \mathrm{NaOH}$ ). The X-ray diffraction data did not show diffraction peaks from crystalline iron oxides/oxyhydroxide. Only the broad band from the amorphous component of the precipitate was observed. The energy dispersive spectra obtained during the scanning electron imaging is shown in Figure 6. The spectra contain peaks for iron and silicon as expected along with sodium from the salt solution. 
WSRC-MS-2003-00759

\section{Potential Silicon Removal in DWPF}

The treatment of DWPF recycle for removing silicon has received substantial review. Initially, an acid-side evaporator was proposed to return the silicon-containing frit within DWPF and send only a small fraction of the volume and silicon to the tank farm. However, a review [6] of the possible options showed the cost and schedule considerations would suggest that a more promising treatment would include acid-side filtration. Figure 7 shows the potentially viable process involving treating recycle water inside DWPF. The proposed process would involve the collection of the recycle constituents followed by filtering the insoluble frit using crossflow filtration. The soluble component of silicon would be minimal due to the low solubility of silicon under these acidic $\mathrm{pH}$ ranges. The filtered frit would be returned to the Slurry Mix Evaporator. The acidic filtrate would be neutralized to an optimum $\mathrm{pH}$. Ferric nitrate would then be added to remove the soluble silicon to concentrations below concern. The caustic slurry containing the iron flocculent would be transferred to the tank farm and incorporated into the sludge for processing in the DWPF or recycled into the Slurry Adjustment and Receipt tank.

\section{Conclusions}

Silicon in the DWPF Recycle stream represents a waste instability when mixed with the more traditional aluminum-bearing waste produced in the separation canyons. This instability eventually fouled one of the Savannah River Site's operating evaporators and curtailed operation for an extended duration. The results of these tests aimed at removing silicon from wastes currently stored in the tank farm and for newly generated wastes in the DWPF have shown that ferric flocculation will produce a ferric precipitate, not unlike sludge, that removes soluble silicon.

The adsorption of silicon onto the ferric precipitates is a classical waste treatment operation and follows a Freundlich isotherm. The capacity of the ferric precipitate is higher than anticipated based on the use of ferric flocculation in municipal wastewater 
WSRC-MS-2003-00759

treatment and is $\sim 0.1 \mathrm{~g}$ of silicon per gram of iron added when targeting a final silicon concentration of $50 \mathrm{mg} / \mathrm{L}$. Optimization of the process for implementation would need to determine the target silicon concentration and the impact of the added iron. The process was effective at removing silicon from both simulant compositions tested. Additionally, ambient and elevated temperature tests indicated that heating the reaction vessel was not necessary. 
WSRC-MS-2003-00759

Table 1. DWPF Recycle Compositions

\begin{tabular}{||l|l|l|l|l||}
\hline Analyte & Units & $\begin{array}{l}\text { Acidic DWPF } \\
\text { Recycle }\end{array}$ & $\begin{array}{l}\text { Neutralized } \\
\text { DWPF Recycle } \\
\text { in RCT }\end{array}$ & $\begin{array}{l}\text { DWPF } \\
\text { Recycle in } \\
\text { TF }\end{array}$ \\
\hline \hline Na & $\mathrm{M}$ & 0.35 & 1.25 & 1 \\
\hline Nitrate & $\mathrm{M}$ & 0.08 & 0.05 & 0.06 \\
\hline Nitrite & $\mathrm{M}$ & 0.24 & 0.2 & 0.25 \\
\hline Free OH & $\mathrm{M}$ & Slightly acidic & 1 & 0.5 \\
\hline Carbonate & $\mathrm{M}$ & $*$ & $*$ & 0.075 \\
\hline Al & $\mathrm{mg} / \mathrm{L}$ & 270 & 250 & $*$ \\
\hline Si & $\mathrm{mg} / \mathrm{L}$ & 620 & 600 & 56 \\
\hline Fe & $\mathrm{mg} / \mathrm{L}$ & 590 & $*$ & $*$ \\
\hline Formate & $\mathrm{mg} / \mathrm{L}$ & 21 & $*$ & $*$ \\
\hline \hline
\end{tabular}

${ }^{\star}$ None added 
WSRC-MS-2003-00759

Table 2. Silicon Data $(\mathrm{mg} / \mathrm{L})$ from Ferric Testing

\begin{tabular}{|c|c|c|c|c|c|c|}
\hline Temp & Initial Vol & Initial Si & Final Si & Amt Fe Added & Mass Si sorbed & Si Capacity \\
\hline oC & $\mathrm{mL}$ & $\mathrm{mg} / \mathrm{L}$ & $\mathrm{mg} / \mathrm{L}$ & $\mathrm{g}$ & $\mathrm{mg}$ & $\mathrm{mg} \mathrm{Si} / \mathrm{g} \mathrm{Fe}$ \\
\hline \hline & & 51.8 & 51.8 & 0.000 & & \\
\hline 50 & 50 & 51.8 & 27.048 & 0.014 & 1.24 & 88.6 \\
\hline 50 & 50 & 51.8 & 20.904 & 0.042 & 1.54 & 36.9 \\
\hline 50 & 50 & 51.8 & 13.2 & 0.056 & 1.93 & 34.6 \\
\hline 50 & 50 & 51.8 & 6.9696 & 0.084 & 2.24 & 26.8 \\
\hline 50 & 50 & 51.8 & 3.9192 & 0.112 & 2.39 & 21.4 \\
\hline 50 & 50 & 51.8 & 27.602 & 0.014 & 1.21 & 86.7 \\
\hline 50 & 50 & 51.8 & 21.296 & 0.042 & 1.53 & 36.4 \\
\hline 50 & 50 & 51.8 & 16.884 & 0.056 & 1.75 & 31.3 \\
\hline 50 & 50 & 51.8 & 10.5 & 0.084 & 2.07 & 24.6 \\
\hline 50 & 50 & 51.8 & 3.9512 & 0.112 & 2.39 & 21.4 \\
\hline Ambient & 50 & 51.8 & 33.666 & 0.014 & 0.91 & 64.9 \\
\hline Ambient & 50 & 51.8 & 22.08 & 0.028 & 1.49 & 53.2 \\
\hline Ambient & 50 & 51.8 & 16.008 & 0.042 & 1.79 & 42.7 \\
\hline Ambient & 50 & 51.8 & 10.974 & 0.056 & 2.04 & 36.5 \\
\hline Ambient & 50 & 51.8 & 4.922 & 0.084 & 2.34 & 28.0 \\
\hline Ambient & 50 & 51.8 & 2.585 & 0.112 & 2.46 & 22.0 \\
\hline Ambient & 50 & 201.5 & 154.56 & 0.014 & 2.35 & 168.1 \\
\hline Ambient & 50 & 201.5 & 124.08 & 0.028 & 3.87 & 138.6 \\
\hline Ambient & 50 & 201.5 & 98.7 & 0.042 & 5.14 & 122.7 \\
\hline Ambient & 50 & 201.5 & 72.404 & 0.056 & 6.45 & 115.6 \\
\hline Ambient & 50 & 201.5 & 39.949 & 0.084 & 8.08 & 96.4 \\
\hline Ambient & 50 & 201.5 & 21.344 & 0.112 & 9.01 & 80.6 \\
\hline Ambient & 50 & 201.5 & 150.88 & 0.014 & 2.53 & 181.3 \\
\hline Ambient & 50 & 201.5 & 117.18 & 0.028 & 4.22 & 151.0 \\
\hline Ambient & 50 & 201.5 & 92.92 & 0.042 & 5.43 & 129.6 \\
\hline Ambient & 50 & 201.5 & 67.05 & 0.056 & 6.72 & 120.4 \\
\hline Ambient & 50 & 201.5 & 43.152 & 0.084 & 7.92 & 94.5 \\
\hline Ambient & 50 & 201.5 & 21.712 & 0.112 & 8.99 & 80.5 \\
\hline
\end{tabular}


WSRC-MS-2003-00759

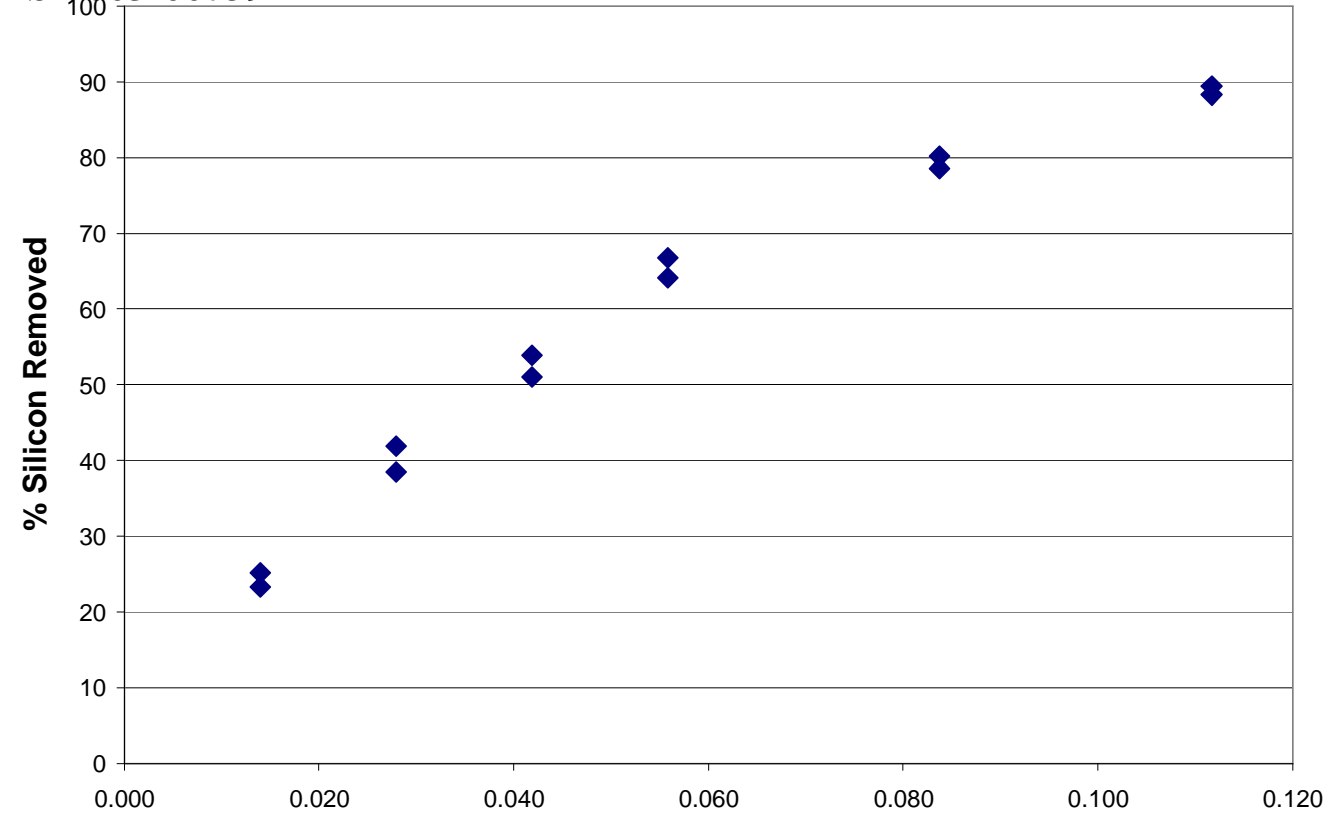

Figure 1. Silicon Removal via Iron AdditforAdditipnbsent Temperature $\left(25^{\circ} \mathrm{C}\right)$ 
WSRC-MS-2003-00759

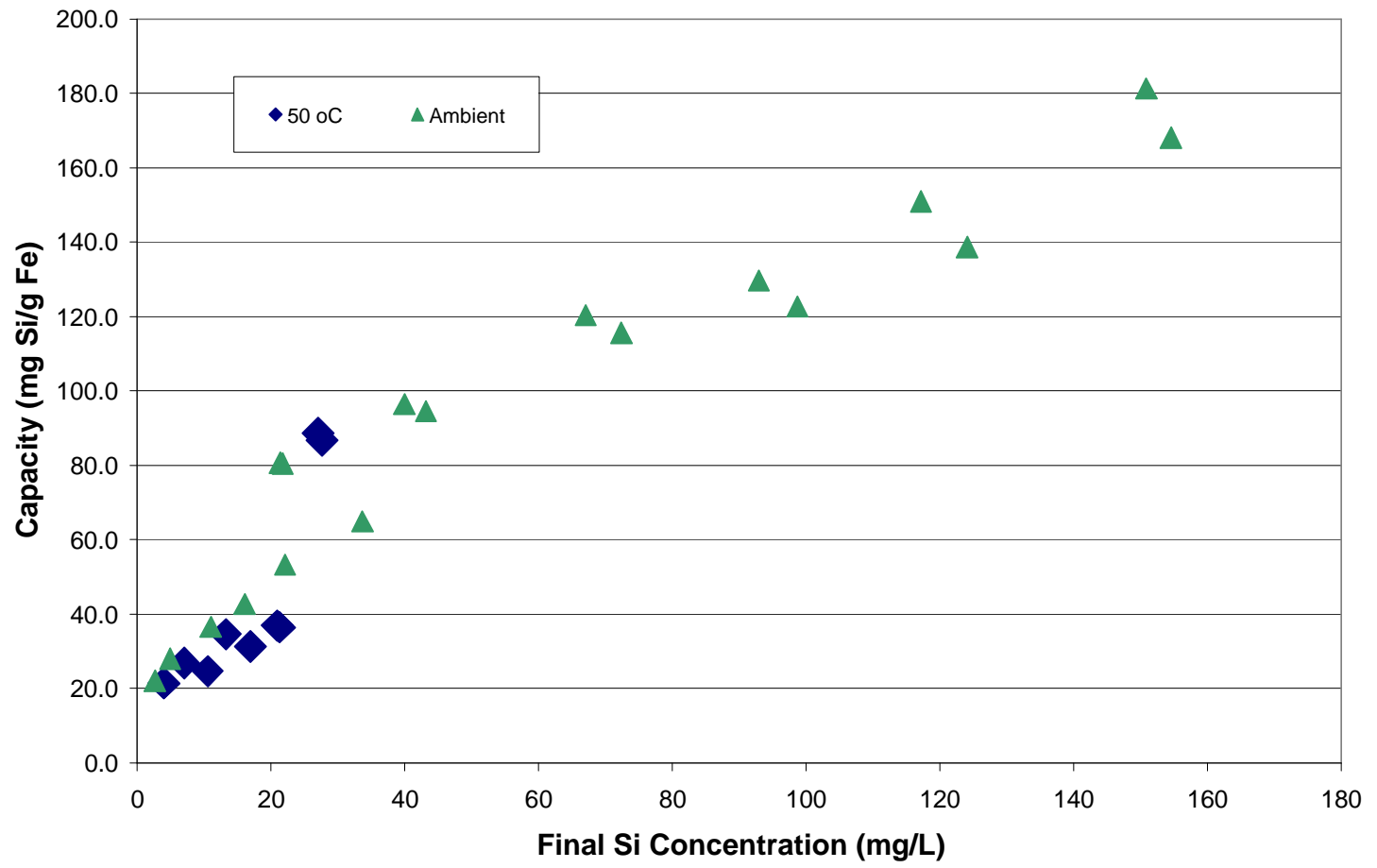

Figure 2. Si Adsorption Isotherm for Tank 20 Simulant 
WSRC-MS-2003-00759

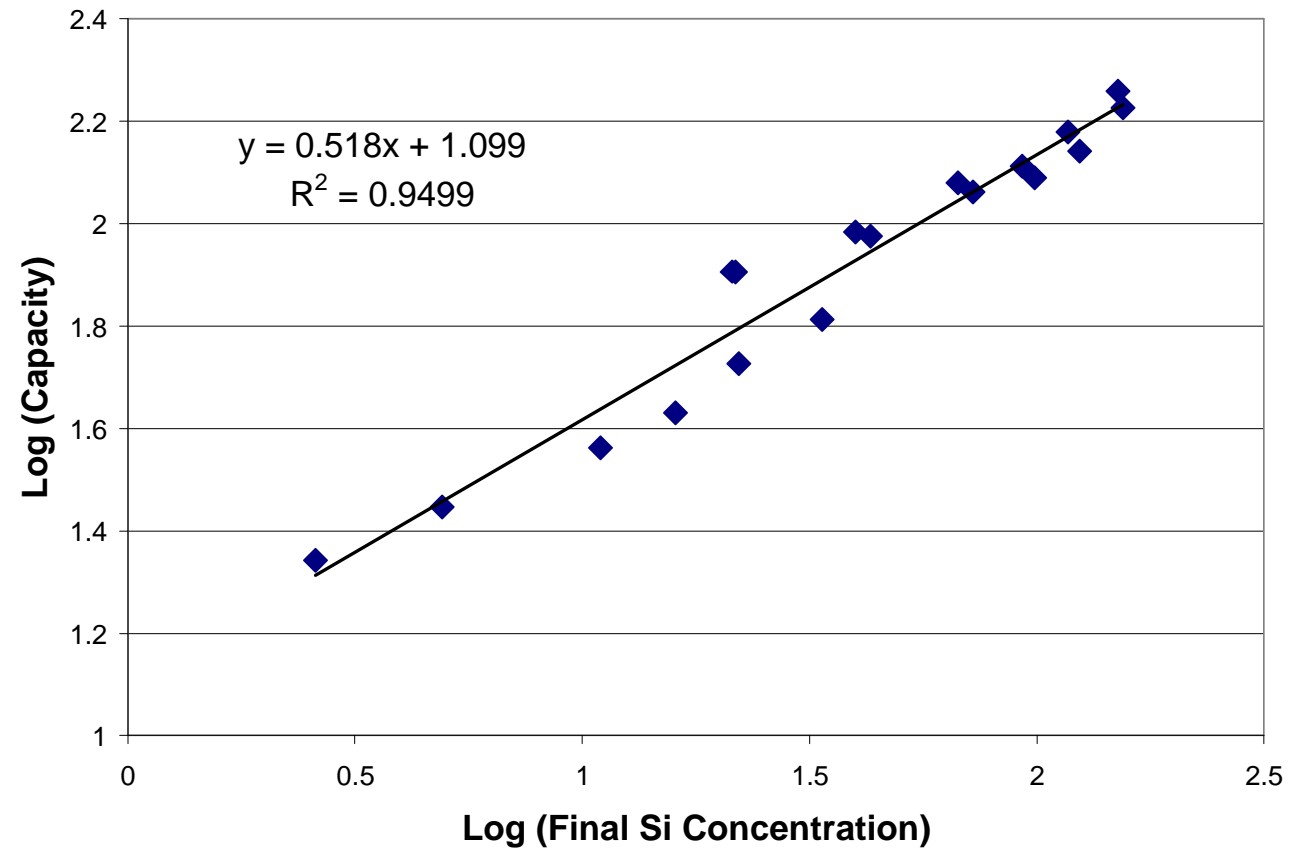

Figure 3. Freundlich Plot of Silicon Adsorption 
WSRC-MS-2003-00759

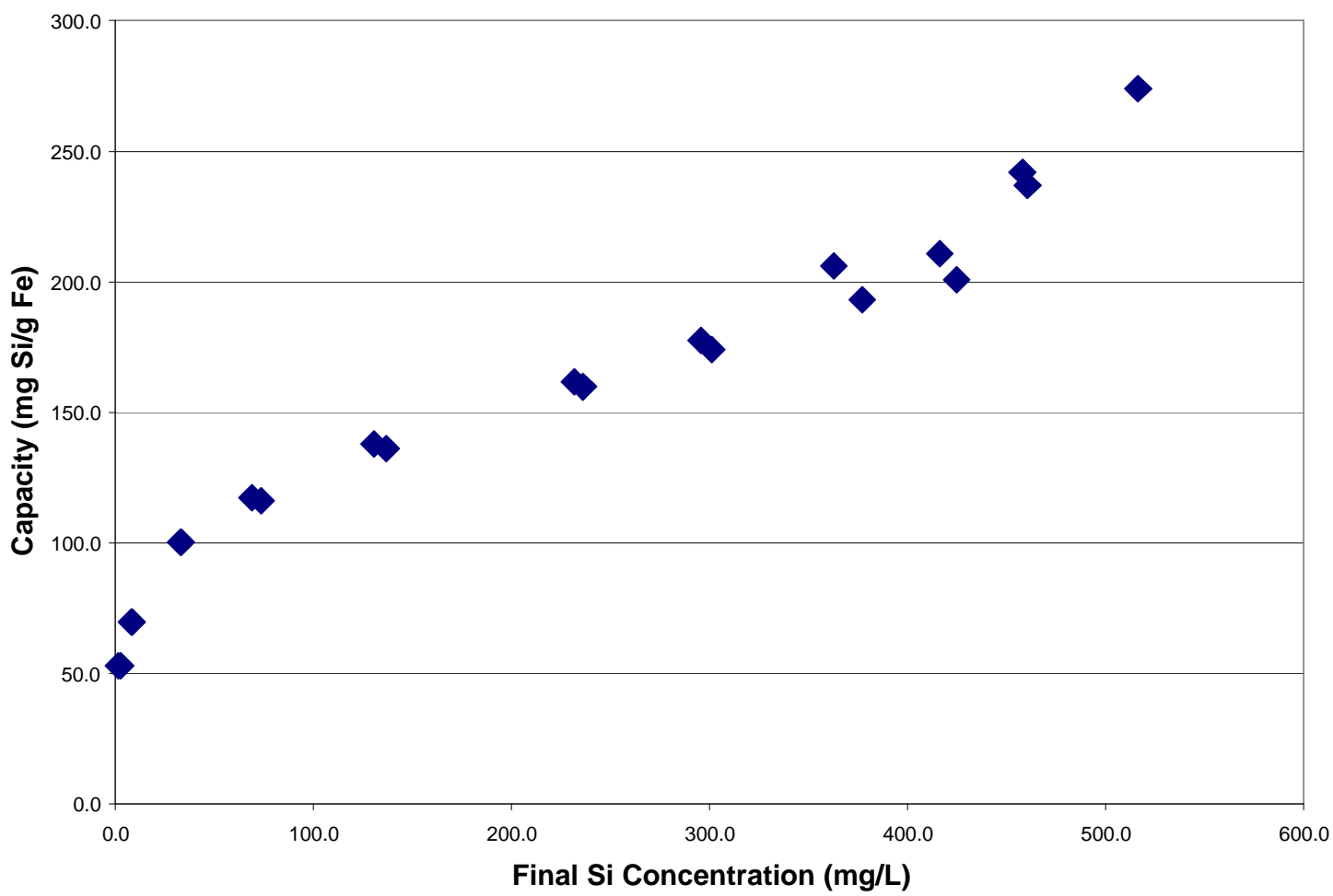

Figure 4. Silicon Removal from Neutralized DWPF Recycle 
WSRC-MS-2003-00759

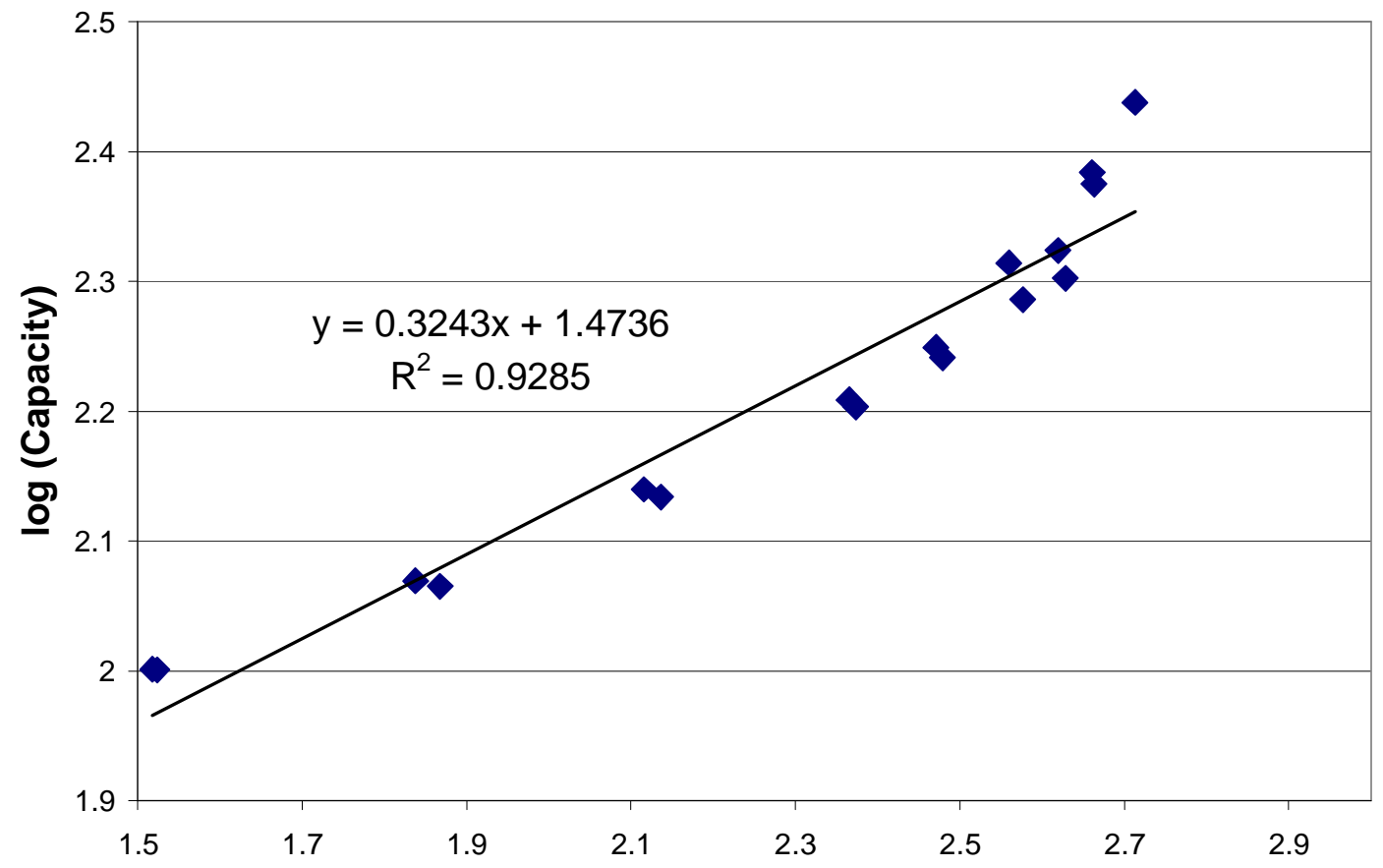

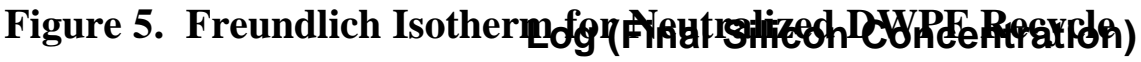


WSRC-MS-2003-00759

ThermoNORAN

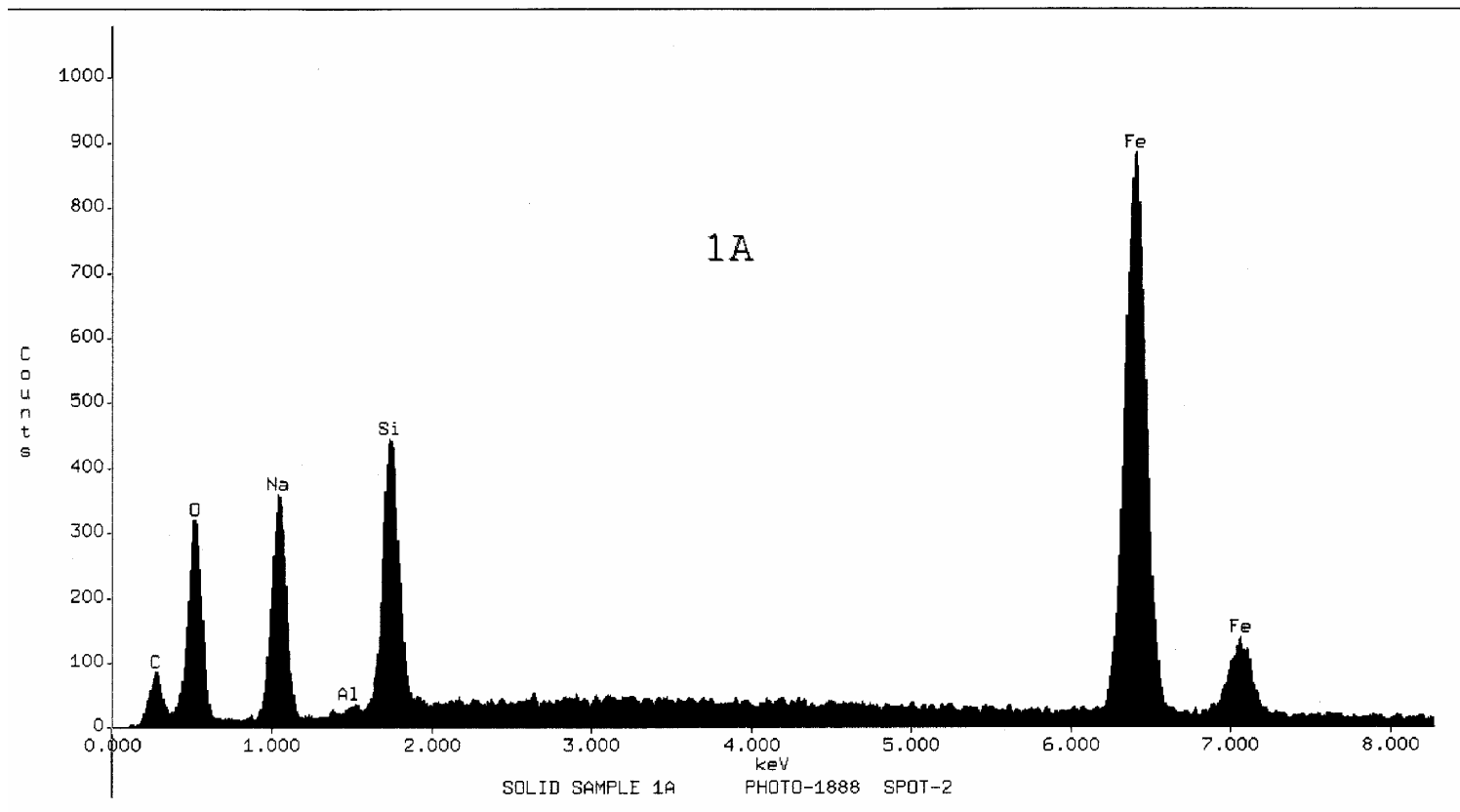

SOLID SAMPLE 1A PHOTO-1888 SPOT-2

Accelerating Voltage: $25 \mathrm{KeV} \quad$ Take Off Angle: $24.2354^{\circ} \quad$ Live Time: 24.81 seconds $\quad$ Dead Time: 6.749 seconds

Figure 6. Energy Dispersive Spectra of Silicon-bearing Iron Precipitate 
WSRC-MS-2003-00759

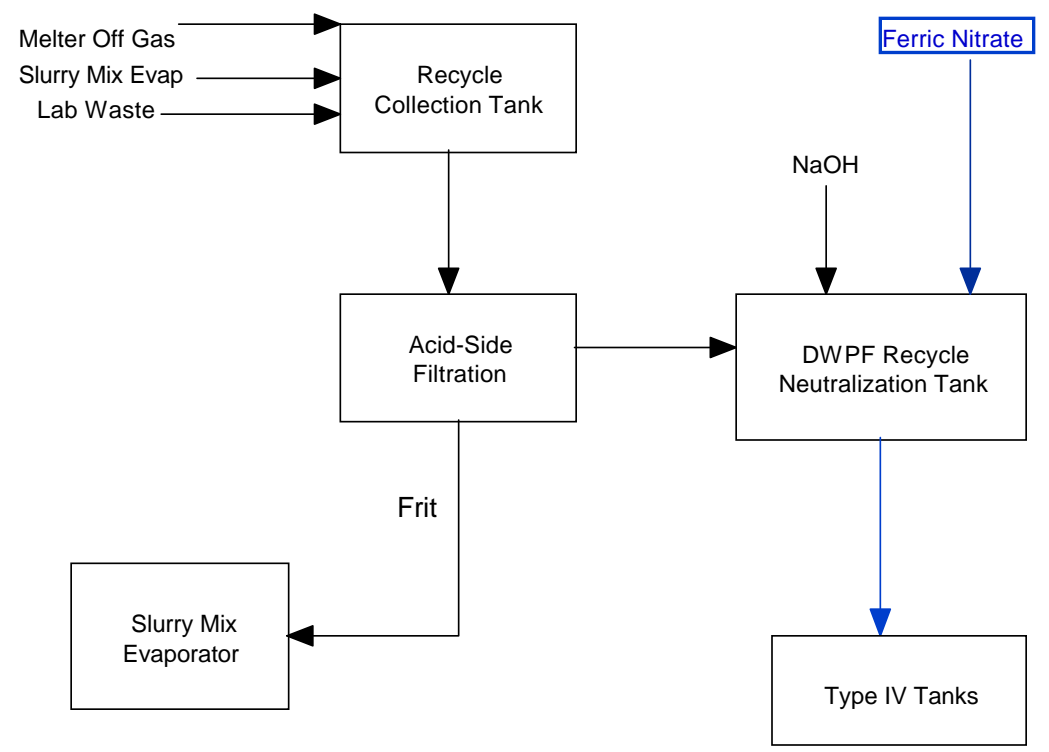

Figure 7. Potential Process for Treating DWPF Recycle

References

1. W. R. Wilmarth, M. C. Thompson, C. J. Martino, V. H. Dukes, J. T. Mills, C. Boley and B. L. Lewis, Sep. Sci. and Tech. $\underline{38}$, 3249, 2003.

2. W. R. Wilmarth, et al., "Aluminosilicate Formation in High Level Waste Evaporators: A Mechanism of Uranium Accumulation," Proceedings WM'02 Conference, February 24-28, 2002.

3. C. R. O'Melia and W. Stumm, J. Colloid and Interface Sci., 23, 437 (1967).

4. F. N. Kemmer, "The NALCO Water Handbook," 2nd Edition, McGraw-Hill, New York.

5. W.R. Wilmarth, S. W. Rosencrance, C. A. Nash, and T. B. Edwards, "Sr/TRU Removal from Hanford High Level Waste,” J. Sep Sci, 36, 2001, p. 1283.

6. R. E. Edwards, "DWPF Recycle Alternative Study," HLW-SDT-2002-0009, January 25, 2002. 